\title{
Göstergebilimsel Film Çözümlemelerinin Bergsoncu Eleştirisi
}

\author{
Mustafa Kemal Sancar*
}

\section{Özet}

Ferdinand de Saussure ve Charles Sanders Peirce tarafindan temelleri atılan göstergebilim çalı̧maları, Christian Metz tarafindan sinema analiz yöntemi olarak kullanılmıştır. Sinemayı bir dil olarak niteleyen Metz; filmlerin en küçük gösterge birimi olan çekimlerin toplamından ibaret olduğunu ileri sürmüştür. Buna göre göstergeler arasındaki yapısal ilişkileri ortaya koyarak filmin içindeki gizli anlamları açı̆̆a çıkarmak mümkündür. Bu çalışmanın amacı, göstergebilimin filmlere yönelik ortaya koyduğu varsayımlar ve filmleri çözümleme yöntemini eleştirmektir. Bu eleştiri için Henri Bergson'un felsefi argümanlarından yararlanılmıştır. Bergson'a göre insan zihni şeyleri iki farklı yolla algılamaktadır: Zekâ ve sezgi yoluyla. Zekâ, hayatın içinde sabit olan şeyleri algılama kabiliyetine sahiptir. Bu nedenle hayatın akışı içinde gerçekleşen şeyler zekâ tarafindan ancak durdurularak ve kavramsallaştırılarak algılanabilir. Sezgi ise şeyleri akış içinde algılama yetisine sahiptir. Bir sinema filmi de zekânın algıladığı sabit şeylerin yanında ancak filmsel akış içinde idrak edilebilecek sezgisel anlamlara sahiptir. Göstergebilimsel film çözümlemeleri, bu sezgi ile kavranabilecek anlam düzeylerini analiz dişında bırakmaktadır. Bir film çz̈zümlemesinde filmin tüm anlam evreni ancak edebi bir dil ile mümkündür. Çünkü filmi izleme akışı içinde gerçekleşen anlamlar yalnızca edebi bir üslupla tarif edilebilir.

Anahtar Kelimeler: Göstergebilim, Film Eleştirisi, Sezgi, Henri Bergson.

ORCID ID : https:/ / orcid.org/0000-0003-0163-4163

E-mail : mkemalsancar@gmail.com

DOI: 10.31122/sinefilozofi.416987

Geliş Tarihi - Recieved: 19.04.2018

Kabul Tarihi - Accepted: 25.06.2018 


\title{
Bergsonesk Critique of Semiotic Film Analysis
}

\author{
Mustafa Kemal Sancar*
}

\begin{abstract}
The semiotics studies based on Ferdinand de Saussure and Charles Sanders Peirce were used by Christian Metz as a method of cinema analysis. Metz, who described cinema as a language, it is the sum of the shootings, which is the smallest sign unit of the films. Accordingly, it is possible to reveal hidden meanings in film by revealing the structural relations between the indications. The aim of this study is to criticize the assumptions of the semiotics for films and the method of analyzing the films. Henri Bergson's philosophical arguments were used for this critique. According to Bergson, the human mind perceives things in two different ways: through intelligence and intuition. Intelligence has the ability to perceive what is constant in your life. For this reason, things that happen in the flow of life can be perceived only by being stopped and conceptualized by intelligence. Intuition has the ability to perceive things in the flow. A film has intuitive meanings that can be perceived only in the film flow, as well as the constant things perceived by intellect. The semiotic film analysis leave out the meaning levels that can be comprehended by this intuition. In a film analysis, film is all possible in the universe but in a literary language. Because the meanings of the film in the flow of watching can only be described in a literary style.
\end{abstract}

Keywords: Semiotics, Film Criticism, Intuition, Henri Bergson.

ORCID ID : https://orcid.org/0000-0003-0163-4163

E-mail : mkemalsancar@gmail.com

DOI: 10.31122/sinefilozofi.416987

Recieved - Geliş Tarihi: 19.04.2018

Accepted - Kabul Tarihi: 25.06.2018 


\section{Giriș}

Film eleştirisi, sinemanın doğuşu ile aynı tarihlerde ortaya çıkmış edebi bir tür ve bilimsel bir analiz biçimidir. Kökenleri yüzyıllar öncesine dayanan edebi eleştiri geleneğinden beslenen film eleştirisi, 20. Yüzyıl boyunca farklı alanlardaki kullanımları çerçevesinde tanıtım amaçlı eleştiri, bilimsel veya felsefi film eleştirisi gibi çeşitli alt-türlere ayrılmıştır. Film eleştirisini bilimsel bir temele oturtma gayreti Saussure ve Peirce'ın temellerini attığı göstergebilim araştırmalarının etkisi ile ortaya çıkmış ve film eleştirmenleri ve analizcileri tarafından özellikle 1960'l yıllardan 20. Yüzyılın sonuna dek yaygın bir yöntem olarak kullanılmıştır. Günümüzde her ne kadar göstergebilimsel yöntemin kullanımı azalsa da (İnceoğlu, 2014) film analizi için taşıdığı tarihsel önem tartışılmazdır. Bunun en önemli nedenlerinden biri göstergebilimsel çözümleme yöntemlerinin ideolojik, ekonomi politik veya felsefi eleştiriler olsun diğer tüm eleştiri biçimlerini beslemesinden ileri gelmektedir.

Bu çalışmada göstergebilimsel film çözümleme yöntemi, filmlere yaklaşımı ve analiz biçimi açısından ele alınmıştır. Göstergebilimsel yöntem ile amaçlanan eleştiriyi bilimselbilimselci bir temele oturtma gayreti, bir sanat olarak sinemayı değerlendirmede bazı sorunları da beraberinde getirmektedir. Bunun en önemli nedeni, bir sinema filminin çekilen her bir sahnenin toplamından daha fazlası olmasıdır. Bu nedenle bir sinema filmini incelemek için parçalara bölmek, bu fazlalığı ortadan kaldırmakta ve eleştiriyi, analizi eksik kılmaktadır. $\mathrm{Bu}$ çalışmada, ileri sürülen bu varsayımı savunmak için Henri Bergson'un felsefesinden yararlanılmıştır. Bergson, insanın zamanı ve uzamı algılayış biçimini ikiye ayırmıştır. Bir insan, dış dünyasını zekâsı ile durdurarak, sabitleyerek ve sezgisi ile oluş, akış içinde algılayabilir. Bu iki farklı algılayış biçimi, sinema deneyimini açıklamak açısından oldukça elverişli imkânlar sunmaktadır. Çalışmada öncelikle göstergebilimin temelleri ve bu yöntem ile sinemanın ilk karşılaşmaları kısaca ortaya konmuştur. Göstergebilimin temellerini atan Ferdinand de Saussure ve Charles Sanders Peirce'in göstergeler ve göstergebilim ile ilgili temel argümanları ile özellikle Christian Metz ve Yuriy M. Lotman'ın sinema göstergebilimi hakkındaki görüşlerinden bahsedilmiştir. Daha sonra Henri Bergson'un felsefi argümanları ile temel dayanakları belirtilen göstergebilimsel yöntemin eleştirisi yapılmıştır. Sinema bir kitle iletişim aracıdır, fakat bundan da öte sinema, hayatı ve gerçekliği akışı içinde ele alma kabiliyetine sahip bir sanat dalıdır. Bu kabiliyeti yansıtmadan sinemayı ele almak, o eleştiriyi veya analizi eksik kılar.

\section{Sinema Göstergebilimi}

Göstergebilim, bilimsel bir yöntem olarak yapısalcılığın temel ilkelerinden doğmuştur. Fakat sıklıkla bu iki kavramın özdeşleştirildiği görülmektedir (Yücel, 1982). Burada göstergebilim olarak adlandırılan yöntem, aslında “dilbilimsel yapısalcılık"tır. Çünkü göstergebilim, dilbilimin yaptığını, dilin dışındaki gösterge dizgelerini (yazın, resim, sinema, müzik, toplumsal ilişkiler vb.) ele alarak çözümlemeye çalışır (Rifat'tan akt. Birkiye, 1984: 17). Dil dişındaki gösterge dizgelerinden ilk kez söz eden ve bu dizgeleri analiz etmenin temel prensiplerini ilk kez ortaya koyan kişi Ferdinand de Saussure'dür. Ölümünün ardından 1916 ' da ders notları düzenlenerek basılan "Genel Dilbilim Dersleri" adlı eserinde Saussure, göstergebilim (sémiologie) adını verdiği bilimin ilkelerini ortaya koymuş ve dilbilimin ancak bu bilim dalının bir bölümü olabileceğini öne sürmüştür. Dilin toplumsal bir olgu olduğunu ileri süren Saussure, göstergebilim yöntemini toplumbilimden hareket ederek inşa eder. Saussure göstergenin de kültürel süreçlerin sonucunda ortaya çıktığını belirtir, çünkü göstergeyi 
meydana getiren gösteren ile gösterilen arasındaki bağ uzlaşımsaldır (Şendur Atabek ve Atabek, 2007: 69). Göstergebilimsel yöntemi Saussure'le hemen hemen aynı dönemde ortaya koyan bir diğer önemli düşünür de Charles Sanders Peirce'dır. Mantık bilimini temel alarak bir göstergebilim yöntemi yaratan Peirce, göstergeyi şu şekilde tanımlamıştır: "Bir kişi için herhangi bir şeyin yerini, herhangi bir bakımdan ya da herhangi bir sıfatla tutan şeydir" (Şendur Atabek ve Atabek, 2007: 70). Peirce'ın gösterge tanımı dahi, kuramındaki mantık bilimi etkisini açıkça göstermektedir.

Göstergebilimin konusu, tözü ne olursa olsun, sinırları ne olursa olsun, her türlü göstergeler dizgesidir: Görüntüler, el-kol-baş hareketleri, ezgili sesler, nesneler ve törenlerde görülen tözlerin karmaşaları (Barthes, 1997: 23)...Göstergebilimin amacı, bu sonsuz çeşitlilikteki göstergeleri ortaya çıkararak yapıların görünen yüzünün altında yer alan gizil anlamları ortaya çıkarmak ve bu vesileyle "yapıları" anlamaktır. "Göstergebilim, kimi kullanımlarda, anlambilimin bir başka adıdır; ancak bu anlambilim, salt sözcüklerin anlamını inceleyen bir bilim dalı olarak düşünülmemelidir. Tüm gösterge dizgelerindeki anlamsal katmanları yapılaştırmayı amaçlayan bir anlambilimdir" (Rifat, 1990: 9).

Göstergebilimsel bir çözümlemenin en önemli ögesi göstergedir. Her göstergebilimsel çalışma, öncelikle ana yapıdaki göstergeleri ortaya çıkarır ve onları tanımlar. "Kendisi o şey olmadığı halde, o şeyi çağrıştırarak iletişim sağlayan her aracı göstergedir" (Erkman, 1987: 10). Saussure'e göre dildeki göstergeler nedensizdir. “Sözel gösterge nedensiz olduğundan, anlam ile içsel veya sabit bir bağıntısı yoktur" (Piaget, 1999: 74). Peirce ise göstergeleri üçe ayırır: Görüntüsel-ikonik göstergeler, belirtisel göstergeler ve simgesel göstergeler. Görüntüsel göstergelerde gösterenle ile gösterilen arasındaki bağ görüntüsel-benzeşimseldir. “Görüntüsel göstergeler de kendi aralarında iki alt sınıfa bölünebilirler: imgeler ve diyagramlar. İmgelerde 'basit özellikler' birbirine benzer; diyagramlarda ise 'parçalar arasındaki ilişkiler' birbirine benzer" (Wollen, 1989: 124). İkinci gösterge biçiminde ise gösteren ile gösterilen arasındaki nedensellik bağı belirtiseldir, mutfaktan ağır kokular gelmesinin çöpleri atmayı unutmanın belirtisi olması gibi. Son olarak gösteren ile gösterilen arasında uzlaşımdan başka bir bağ olmayan göstergeler ise simgeseldir. Göstergenin üçüncü türü olan simge Saussure'ün rastlantısal göstergesine denk düşer. Saussure gibi Peirce de simgeyi bir gösterge haline getiren bir 'anlaşmadan' söz eder (Wollen, 1989: 125).

Burada dilde veya insan yaşamının kendisinde yer alan göstergeler ile sinemasal göstergeler arasındaki farkı ortaya koymak gereklidir. Sözcükler çift eklemleme gücünü sahiptirler. Dildeki göstergelerin sahip olduğu imaj ve göstergelerin işaret ettikleri imaj bir aradadır. Fakat sinemadaki göstergeler ile gösterilenler arasındaki ilişki hemen hemen aynı düzlemde yer alır. Perdede gösterilen bir obje ile objenin kendisi -nadiren aynı boyutlarda olsalar da- hemen hemen aynıdırlar. Sinemasal gösterge ile gösterilen şeyin aynı boyutta olması gerekmez. Önemli olan bu iki imajın içinde bulundukları uzamda tutarlı olmalarıdır. Sinema perdesine yansıtılmıs dev bir kaleme şaşırmayız, ta ki o kalemin içinde bulunduğu oda veya üzerinde bulunduğu masa ile olan görsel ilişkisini görünceye kadar.

Yukarıda kısaca çerçevesi çizilen göstergebilimsel yöntemi yıllar içinde Claude LeviStrauss antropolojiye, Fernand Braudel tarihe, Jacques Lacan psikanalize, Roland Barthes edebiyata ve Christian Metz de sinemaya uygulamıştır. Metz kısaca göstergebilimsel yöntemi, sinema filmlerindeki gizil anlamları ortaya çıkarmak için kullanmıştır. "Semiyoloji, bir filmin seyredilmesini mümkün kılan yasaları saptamaya ve her tekil filme veya sinema 
türüne özel karakterini kazandıran özgün anlam ve kalıplarını ortaya çıkarmayı amaçlar" (Andrew, 2010: 324). Bu amaç doğrultusunda göstergebilimci, öncelikle sinemanın kendisine yönelmek ve ondan yola çıkmak zorundadır. "Sinema alanının kalbinde sinematografik olay, sinematografik olayın çekirdeğinde ise anlam süreci vardır. Göstergebilimci doğrudan doğruya bu çekirdeğin içine yönelir" (Andrew, 2010: 325). Bu çekirdekteki en küçük yapı, tek tek sahnelerdir. Göstergebilimci, çekilen her bir sahne ve sahneler arasındaki anlam ilişkisi içinden genelleştirilebilecek bilimsel veriler elde eder. Sinemanın bir dil (langue) değil, dilyetisi (langage) olduğunu ileri süren Metz (2012: 66), "Sinemada Anlam Üzerine Denemeler" adlı eserinde, yalnızca genel dilbilim ve genel göstergebilimin sinematografik dilyetisinin incelenmesi konusunda uygun yöntemsel 'modeller' sunabildiğini ortaya koymaktadır (Metz, 2012: 131).

Çoğu sinema tartışması ve film eleştirisi, bir filmin ne söylediği (mesajları) üzerinde yoğunlaşır. Semiyotik ise, sinemanın kendi olanakları ölçüsünde, bu mesajları yöneten yasaları keşfetmeyi amaçlar. Semiyotik metnin (filmin) söylediğini tekrar etmez. Bunun yerine ham maddeden mesajların çıkmasına olanak veren mantıksal mekanizmaları yakalamayı amaçlar (Andrew, 2010: 332).

Christian Metz, film eleştirisini bilimsel bir temele oturtmak iddiasındadır. Amacı filmlerin tek tek çözümlemesi neticesinde tüm filmlere uygulanabilecek yasalar ortaya koymaktır. $\mathrm{Bu}$ nedenle göstergebilimin dilbilim içinde gerçekleştirdiği bilimselci tavrın sinema filmlerinde de uygulanabileceğini ileri sürer. Çünkü sinema da bir dildir. Sinemanın diğer dillerden tek farkı iletişimsel yönünün ikinci planda olmasıdır. Bu nedenle insanlar arasında konuşulan dilin taşıdığı tüm yapısal özellikler sinema dilinde de vardır. Metz'e göre sinemanın ham maddesi asla gerçekliğin kendisi veya montaj oyunları gibi özel anlam araçları değildir. Filmin ham maddesi, filmi seyrederken dikkat ettiğimiz bilgi kanallarıdır. Bu kanalları şu şekilde sıralamak mümkündür:

1. Fotoğrafik, hareket eden veya bunları birleştiren imgeler.

2. Perde dışından okuduğumuz bütün yazılı materyalleri içeren grafik çizimler.

3. Kaydedilmiş konuşmalar.

4. Kaydedilmiş müzik.

5. Kaydedilmiş gürültü veya ses efektleri

Sinema göstergebilimcisi, yalnızca bu malzeme karışımından çıkan anlamla ilgilenen bir analizcidir (Andrew, 2010: 325). Bu beş ham madde çeşitli anlamlamalar ortaya çıkarır. Seyircinin bu ham maddelerden aldığı veri, kendi kültürel arka planı ile karşılaştığında anlam ortaya çıkar. "Metz'e göre görüntü anlamını kültürel kodlardan ötürü ya da bağlamdan ötürü edinir. Her görüntü tek başına bir anlam taşır, ama başka görüntülerle birlikte olduğunda yeni yan anlamlar edinir" (Büker, 2012: 42). Bir göstergebilim çözümlemesinin temel hedefi bu anlamları ve yan anlamları ortaya çıkarmak ve buradan genelleştirilebilecek verilere ulaşmaktır. "Metz, normal kurgu sinemasında, çekim-sekans, değişen syntagm (dizim, sentagma), sahne ve benzeri olaylar arasında olası sekiz ana bağlantı türü saptamıştı. Tek tek türler, auteurler veya dönemler arasındaki bağlantıların özel kullanımını inceler ve sinemanın anlatı kapasitesinin verili koşullar altında gerçekleştirildiğini anlatır" (Andrew, 2010: 343). 
Yan anlam, göstergebilimsel bir analizde filmin derinlerine inmek için gereken en önemli verileri sunar. Çünkü filmin kültürel veya toplumsal bağlamını yan anlamlar ortaya çıarır. Örneğin Vizontele (2001, Yılmaz Erdoğan, Ömer Faruk Sorak) filminde Nazmi Doğan (Altan Erkekli) adlı karakterin çocuğu öldükten sonraki uzun sakallı görüntüsü, ancak Türkiye kültürü içinde anlaşllabilecek bir yan anlamsal imgedir. Bir filmin, seyircinin zihninde oluşturduğu anlamları ortaya çıkarmak, yukarıdaki örneğe benzer yan anlamların açımlanması ile mümkün hale gelir. Fakat bir filmin yarattığı anlamlar yalnızca yan anlamlar aracılığıyla gerçekleşmez. Dildeki parçaüstü birimlere benzer anlam yapıları da sinemada anlamı yaratan etmenler arasında sayılabilir. Dildeki parçasal birimler tek tek harfler iken; parçaüstü birimler, konuşurken bu harflere yaptığımız vurgulardır. Örneğin "efendim" kelimesini telaffuz ediş biçimimiz, bu kelimenin bir hitap kelimesi olarak veya "Ne dediğinizi anlamadım." olarak anlaşılmasına neden olabilir. "Metz'e göre sinema dilinde de parçasal ve parçaüstü birimler vardır. Sinema dilinin parçasal birimleri çekim, ayrım vb. gibi uzamda yer kaplayan ögelerdir. Sinemanın parçaüstü birimleriyse renk, alıcı devinimleri, geçişler gibi uzam ve zamanda yer kaplamayan ögelerdir" (Metz'den akt. Büker, 2012: 56). Bir sinema filminin her bir sahnesi veya sekansların her biri o filmin parçasal birimlerini meydana getirir. Bir de filmin parçaüstü birimleri vardır. Örneğin filmin bir bölümünde renk siyah-beyaz veya sepya tonlarına geçtiğinde, filmsel zamanda bir flashback yaşandığı anlamını çıkarabiliriz. Veya filmin bir bölümünde kamera bir karakterin baktı̆̆ı yönü bulanık gösteriyorsa, buradan o karakterin gözlerinin bozuk olduğu veya sarhoş olduğu anlamı çıkabilir. Göstergebilimsel bir analizde, parçasal birimlerin incelenmesi kadar, parçaüstü birimlerin de analize konu edilmesi gereklidir.

Metz, sinemayı iki bölüme ayırır: Filmsel olan ve sinemasal olan. "Filmsel ile kastettiği, sinemanın diğer etkinliklerle ilişkisini ele alan soruların sınırsız alanıdır. Bir film yapılmasının içine giren her şey (teknoloji, sınai örgütlenme, yönetmenlerin hayat öyküleri vb.) ve filmlerinin varlığının bir sonucu olarak düşünülebilen bütün boyutlar (sansür yasası, izleyici tepkisi, star kültü) buna dahildir. Sinematografik alan ise daha dardır; hem kendisini yaratan karmaşıklıkları hem de kendisinin ürünü olan karmaşıklıkları dışta bırakır" (Andrew, 2010: 324). Bu ayrımda genel olarak sinema anlatı anlamindadır, fakat filmin ayırt edici niteliği sarih değildir (Ehrat, 2005: 172). Bu nedenle Metz, sinema göstergebiliminin "sinema" ile yani anlatının kendisi ile ilgilenmesi gerektiğini öne sürer. Göstergebilimsel film çözümlemelerine getirilen en popüler eleştiri, bu yöntemin metnin kendisini merkezine alarak, metin dışı faktörleri göz ardı ettiği yönündedir. “Göstergebilim (semiyoloji) filmsel alanın, filmin dışsal yanlarının araştırılmasını, sosyoloji, ekonomi, sosyal psikoloji, psikanaliz, fizik ve kimya gibi başka ilgili disiplinlere bırakır. Metz ve izleyicilerinin ele almayı seçtiği konu, filmin mekaniğinin içsel araştırmasıdır" (Andrew, 2010: 324). Burada dikkat edilmesi gereken iki önemli husus bulunmaktadır. Öncelikle Metz'in film-sinema ayrımı, sinema veya anlatı dışı disiplinlerin araştırma konusu edilmemesi gerektiği sonucuna vardırılmamalıdır. Göstergebilimci; sosyoloji, psikoloji, estetik, tarih vb. gibi bilimlerden aldığı verilere dayanır, bu bilimlerden aldığı yöntemlere değil (Özden, 2004:153). Bir diğer önemli husus da Metz' in bu ayrımının; sinemanın ekonomik, sosyal ve politik bir yapı olarak eleştiri dışı olduğu anlamına gelmediğidir. Metz, sinemanın bir kurum olarak irdelenmemesi gerektiğini asla tartışmaz; o yalnızca böyle bir çalışmanın film dilbilimi açısından olmazsa olmaz bir niteliği olmadığını belirtir (Stam, 1986). 
Göstergebilimsel film çözümlemelerine getirilen bir başka yaygın eleştiri de yöntemin uygulaması zor ve karmaşık olduğu yönündedir. Göstergebilim terminolojisinin, yöntembiliminin zorluğu ve filmleri en küçük parçalarına ayırarak inceleme yönteminden ötürü göstergebilimin bize zaten bildiğimiz şeyleri hiç anlayamayacağımız bir dille anlattığ1 dillendirilmektedir (Özden, 2004: 138). Bir filmi izlediğimizde, zihnimizde bazı açık ve örtük anlamlar ortaya çıkar. Bu film ile ilgili göstergebilimsel bir analiz yapıldığında, izleyicinin hangi anlamları çıkardığı sorusuna verdiği yanıtlar, gerçekten de zaten bilinen birçok olguyu karmaşıklaştırdığı anlamına gelebilir. Fakat göstergebilimsel bir analiz yalnızca bununla yetinmemelidir. Yapılan analiz neticesinde filmin yarattığ bu anlamlamaların hangi süreçlerden geçerek nasıl gerçekleştiğini de ortaya çıkarmalıdır. Tüm bu sorulara yanıt veren göstergebilimsel bir film çözümlemesi, yapılan eleştirileri haksız çıkaracaktır.

Göstergebilimsel çözümlemenin en önemli katkılarından biri, hiç kuşkusuz bir sinema filminin analiz edilebilir doğasını öne çıkarma başarısıdır. "Hiçbir yaklaşım tek başına verili bir metin içindeki anlam noktalarını tüketemezken, bu formal içerik çözümlemesi, bulgularının tekrarlanmasını sağlayacak kadar büyük bir kesinlik içinde eleştirmenlerin filmleri anlam düzeyinde tartışmalarına ve kıyaslamalarına olanak tanımaktadır" (Özden, 2004: 138). Sinema filmlerinin formal yönünü çözümleme nazarında ortaya çıkarması, sinema çalışması yapan profesyoneller kadar seyircinin de seyir teamüllerini dönüştürmüştür. Göstergebilimsel eleştiri, pasif bir anlam tüketicisi olarak seyirci ya da profesyonel bir seyirci olarak film eleştirmeni kavramı yerine, aktif bir anlam üreticisi olarak film seyircisi ya da eleştirmeni düşüncesinin geliştirilmesini sağlamıştır (Özden, 2004: 140).

Yukarıda saydığımız tüm bu inkişafa rağmen göstergebilimin sinema eleştirisine katkısının sınırlı olduğunu söylemek gerekir. Bir filmi bilimsel metodlarla çözümlemek, ister istemez o sanat yapıtının insanda bıraktığı aşkın durumu açıklamakta yetersiz kalmaktadır. "İmajlar bizlere çarptığında oluşan duygulanım, sadece bilgi düzeyinde anladığımız fikri bize imgesel düzeyde hissettirebilir ve fikir değişik çatallanmalarla yeni fikirlere yol açabilir" (Öztürk, 2018: 53-54). Bu çatallanmalar ve ortaya çıkardıkları fikirler, imgelerin yan yana gelerek oluşturduğu sözdizimsel formüllerin ötesinde belirli felsefi sorgulamalar ile ortaya çıkabilir. Bir sonraki bölümde Henri Bergson'un sezgi felsefesinden yararlanarak bir filmin kurgu yolu ile bitiştirilmiş imgelerden ibaret olmadığı ve bu nedenle bir filmi anlamak için göstergebilimsel yöntemin ötesine geçmek gerekliliği üzerinde durulacaktır.

\section{Bergson'un Sezgi Felsefesi}

Henri Bergson (1859-1941), ortaya koyduğu felsefesi ile yaşadığı dönemden günümüze kadar gelen birçok felsefi düşünceyi bir biçimde etkilemiş önemli bir düşünürdür. Önce döneminin yaygın düşünüş biçimi olan bilimselci-pozitivist bir anlayışa sahip olan ve Herbert Spencer'ın evrim anlayışın benimseyen Bergson, daha sonra bu düşüncesini terk etmiş ve kendi "yaratıcı evrim" düşüncesini geliştirmiştir. "Bir bütün olarak gözden geçirildiğinde Bergson'un felsefesi bir düalizm olarak karşımıza çıkar: Madde-Hayat, İçgüdü-Zekâ, MekânZaman, Ruh-Beden, Statik Toplum-Dinamik Toplum, İnsani Ahlak-Toplumsal Ödev Ahlakı" (Gündoğan, 2013: 52). Söz konusu ikilikler içinde bu çalışmanın özellikle üzerinde duracağ1 konular zaman-mekân ve sezgi-zekâ ikilikleridir.

Gilles Deleuze, sezgiyi Bergsoncu bir yöntem olarak addeder. "Sezgi bir duygu, bir esinleniş ya da belirsiz bir duygudaşlık değildir. $\mathrm{O}$, gelişmiş bir yöntemdir, hatta felsefenin 
en gelişmiş yöntemlerinden biridir" (Deleuze, 2014: 53). "Deleuze'ün Bergsonculuğun anlaşılmasına yaptığı en büyük katkılardan biri, Bergson'un sezgiyi nasıl yetkin bir felsefi yöntem haline getirdiğini kusursuz bir yorumla gözler önüne sermesidir" (Yücefer, 2014: 18). Deleuze'e göre sezgi, Platoncu ruha sadık bir bölme yöntemidir. Deneyimi, deneyimin koşulları yönünde aşmamızı sağlayan bu yöntem ile olanı yalnızca olması gereken düzeyinde varolan eğilimlere ya da saf mevcudiyetlere bölme işlemidir. Böylece deneyim, deneyimin koşulları bakımından aşılmış olur (Deleuze, 2014: 62-63). Burada aslında Bergson'un açık bir biçimde belirtmekten imtina ettiği felsefi yöntemi Deleuze' ün açımladığını görmekteyiz. Fakat Deleuze bununla da yetinmez ve Bergsonculuk adlı eserinde bu yöntemin aşamalarını gözler önüne serer. Deleuze'e göre Bergson'un sezgi yöntemi şu aşamalardan oluşur: 1. Problemler ortaya koymak (yanlış problemlerin eleştirisi ve doğruların icadını içerecek biçimde) 2. (Parçalara bölmek ve kesiştirmek anlamında) farklılaştırmak 3. Zamansallaştırmak (yani sürenin terimleriyle düşünmek) (Deleuze, 2014: 75). Bu yöntem ile ulaşılmak istenen gaye, dolaysıza ulaşmak için, kendini doğrudan sunan nesnenin ötesine geçmek ve nesnenin ardında nesneye özgü olan dolaysız farkı aramaktır. "Sezgi, nesnenin kendisinden nesnenin farkına, doğrudan verilenden dolaysız verilere, deneyimden deneyimin koşullarına dönüştür" (Yücefer, 2014: 18).

Bergson'a göre insanın algılayışı iki farklı vasıtayla gerçekleşir: Zekâ ve sezgi. Zekâ, oluş içerisindeki duraklar vasıtasıyla algılamayı gerçekleştirir. Bu duraklar hemen hemen hiçbir zaman algılayış alanımızda var olmadıkları için oluş-akış sırasında zekânın algıyı yaratabileceği duraklar öngörmesi gerekmektedir. Bergson felsefesinde bu duraklar, zamanın zekâ marifetiyle mekânsallaştırılması anlamına gelmektedir.

"Zamanın anlarn ve devingenliklerin konumlarn sadece, müdrikemizin hareketin ve sürenin sürekliliği üzerinden çekmiş olduğu birtakım enstantane fotoğraflardan ibarettir. Birbiri üzerine yığılmış olan bu manzaralarla zaman ve hareketin, hesabın zaruretlerine uygun geleceği âna kadar dilin zaruretlerine boyun eğen bir mütenebbi elde edilmiş olur; fakat elde edilen şey sadece uydurma bir yeni baştan yapılan tertiptir. Zaman ve mekân başka şeydir" (Bergson, 1959: 10-11).

Bergson felsefesinde zaman, yaygin bilimsel kanaatin aksine çizgisel, dairesel veya sayısal bir nitelik taşımaz. "Dışımızda yani mekânda tasarladığımız zaman matematik zamandır. O gerçek zaman değildir, bizim tarafımızdan uydurulmuştur" (Topçu, 2015: 37). Zamanın en önemli niteliği devingenliğidir ve bu sonsuz hareketi hiçbir biçimde bölü(m) lenemez. "Ölçülen çizgi devinmez, zaman devinir" (Bergson, 1959: 5). Zamanı sayısallaştırmak, öngörülebilir olması beklenen dünya tahayyülümüz için son derece elzemdir. Fakat bu işlem, zamanın izafi yönünü karanlıkta bırakmakta ve zamanı algılayış biçimimizi bozmaktadır. "Biz zamanı, bir çizgi veya çember olarak ifade ettiğimiz anda zamanın hareketi sonlanır. İstemeden zamanı mekânsallaştırmış oluruz" (Guerlac, 2006: 1). Elektronik bir saat yardımıyla ölçtügümüz bir dakikalık zaman dilimi, zamanın ve uzamın içinde tam olarak ne kadar yer kaplamaktadır? "Zaman son derece hızlanabilir ve hattâ sınırsız bir şekilde hızlanabilir: Matematikçi için, fizikçi için, astronomici için hiçbir şey değişmiş olmaz" (Bergson, 1959: 6). Matematikçi veya fizikçinin zamanı ele alış biçimi, Bergson felsefesinde zekânın algılayış biçimine denk düşer.

Bergson'a göre insan ruhu ve şuuru için söz konusu olan zaman ile insanın dışında ortaya çıkan zaman diye bir ayrım vardır ve bu ayrım, süre ile zaman ayrımına da denk düşer. Süre kavramı, insan ruhu ve şuurunda cereyan eden zaman kavramı için kullanılırken; insan dışında maddi 
evrende geçen zaman için kullanılmamaktadır (Gündoğan, 2013: 74).

Zekâ; durdurarak, sayısallaştırarak ve mekânsallaştırarak algılar. Sezgi ise oluşakış içinde algılar. "Sezginin bize gösterdiği ilk şey, yaygın zaman kavrayışımızın aslında zamana yabancı olan, uzama ait ölçütlerle belirlendiği, ama bilincimizin bu zamanın ötesinde kendine özgü içsel bir zamana ait olduğudur" (Yücefer, 2014: 26). Zekâ; algıladıklarını kavramsallaştırabilir, betimleyebilir veya analiz edebilir. Sezgi ise algıladıkları çerçevesinde kendisini dönüştürebilir, fakat bunu kavramlarla ifade etmesi veya betimlemesi oldukça güçtür.

"Zekâmız, kendi doğal akış yönünü takip ettiğinde, bir yandan kalıcı algılarla, diğgr yandansa yerleşik/stabil kavramlarla i̧̧ görür. Hareketsiz olandan yola çıkar ve hareketi sadece, hareketsizlik bakımından kavrar ve açılar. Hazır kavramların içine yerleşir ve geçip gitmekte olan realiteden bir şeyleri sanki bir ă̆ ile toplamaya çabalar" (Bergson, 2013: 75).

Bergson'un burada ortaya koyduğu "sanki bir ağ ile toplamak" benzetmesi, zekânın algılayışını somutlaştırmamız için oldukça önemli bir imkân sunar. Zekâ, gerçekliğin içinden, o gerçekliği kavrayabileceği bazı enstantaneleri "sanki bir ağ ile" toplar. Bu enstantaneler, akışın içinden çekilen fotoğraf kareleridir. "Gerçek olan, bizim çektiğimiz birtakım basit enstantane fotoğraflar olan 'durumlar' değildir; bu dahi değişiklik dilidir; tersine olarak gerçek olan şey akıştır, intikal sürekliliğidir, değişikliğin kendisidir" (Bergson, 1959: 11). Sezgi ise gerçeği akış içinde algılar, bu nedenle sezgi vasıtasıyla gerçeğin su yüzünde görünmeyen boyutuna erişilir. "Sezi devimden işe başlar, devim vazeder veya daha doğrusu onu gerçeğin kendisi olarak sezer ve devingensizlikte ise ancak soyut, zihnimizce bir devingensizlikten çekilmiş enstantane bir lâhza fotoğrafı görür" (Bergson, 1959: 37). Sezgi ile zekâ arasında Bergson'un dikkat çektiği farkı ortaya koymak için hakkında bilgi-enformasyon edindiğimiz bir şey ile aynı şeyi deneyimlememiz arasındaki farkı düşünebiliriz. Şüphesiz bir şehri deneyimlemek ile o şehrin fotoğraflarını görmek veya o şehir hakkında bilgi edinmek arasında büyük bir uçurum vardır. "Bir şehri gören bütün mümkün noktalardan çekilmiş bütün fotoğraflar sonu gelmez bir şekilde boş yere birbirini tamamlayacak, dolaştığımız şehir olan bu üç boyutlu ilk örneğe hiç mi hiç denk olmayacaktır" (Bergson, 2013: 42). Bir şehirde belirli bir süre geçirmek, o şehre özgü otantik bir duygu bırakır. Yemek yemek veya bir şeyler içmek hissi bile o şehirde var olmanın parantezi içinde kalır. Bu hissi hiçbir bilgi veya fotoğraf tam olarak yansıtamaz. Bu duygu ancak başarılı bir sanat eseri vasıtasıyla -kısmen de olsa- yansıtılabilir. Bunun en açık örnekleri Fyodor Mihayloviç Dostoyevski (Petersburg), James Joyce (Dublin) ve Orhan Pamuk'un (İstanbul) yaşadıkları şehirler ile özdeşleşmiş romanlarıdır. Bu yazarlar, romanlarında -ele aldıkları konular her ne olursa olsun- kendileri ile özdeşleşen şehirlerin otantikliğini yeniden yaratmayı ve okuyucuya aktarmayı başarmışlardır. Bir şehrin deneyimini edinmek, o şehirde geçirilen zamanın akışı içinde mümkündür. Sanat yapıtları da aynı deneyimi kendi yarattıkları zaman akışı içinde taklit edebilirler. "Bergson, durgun olmayan, akıcı ve yaratıcı bir durumu, olmuş bitmiş olanı değil de oluşmakta olanı anlatmaya çalıştığı için, hayata dişarıdan değil, içeriden bakarak konuşmaktadır" (Gündoğan, 2013: 20). Sanat yapıtları da Bergson'un felsefede yaptığı gibi hayata içeriden bakabilirler.

Bergson, zamanı çizgisel olarak düşünmeyi reddeder. Onun düşüncesinde zaman; geçmiş, şimdiki zaman ve gelecek adlı noktalardan oluşmaz. Bergson'a göre zaman sonsuz şimdilerden meydana gelmiş bir bütündür. "Burada sadece, değişikliğin aralıksız bir ilerleyişi vardır, sonsuzcasına uzayıp giden bir sürede daima kendi kendine uygun ve bitişik bir 
değişikliğin aralıksız bir ilerleyişi vardır" (Bergson, 1959: 11). Fakat bu akışı adlandırmak ve üzerine bir şeyler inşa etmek mümkün olmadığı için insan zekâsı zamanı bölümlemek arzusu içindedir. "Bizim faaliyet ve etkimiz ancak sabit noktalarda kendini gösterir; demek oluyor ki zekâmızın araştırdığı sabitliktir; zekâmız devingenin nerede olduğunu, devingenin nerede olacağını, devingenin nereden geçtiğini sorar" (Bergson, 1959: 9). Zekâ, algılamak ve yeniden yaratabilmek için durdurur ve parçalara ayırır. Bergson, "Düşünce ve Devingen" adlı eserinde bu meseleyi müzik örneğinden yola çıkarak şu şekilde açıklar:

Bir melodiyi, kendimizi onun peşine salivererek dinleyelim: Bir devingene bağh olmayan bir hareketin, kendisini değiştirecek hiçbir şeysiz bir değişikliğin apaçık kavranılışına varmış olamaz mıyız? Bu değişiklik kendi kendine yeterli gelir, şeyin tâ kendisidir. Hem onun zaman alması boşunadır, o bölünemezdir: Melodi daha önce duruverseydi artık aynı sesli yı̆̆ın olamazdı; yine bölünmez başka bir sesli yığın olurdu. Şüphesiz biz onu bölmeye ve onu, melodinin kesiksiz sürekliliği yerine, ayrn ayr birtakım noktaların üst üste gelişi diye tasarlamaya meyledeceğiz. Ama niçin? Çünkü, dinlenilen sesi kendimiz çı̆̆ırarak şöyle böyle yeni baştan yapıvermek için yapacağımız çabaların sürekli dizisini düşünürüz ve çünkü bizim işitme kavrayışımı, görüm hayalleri ile senli benli olmak alışkanlığını edinmiştir (Bergson, 1959: 199).

$\mathrm{Bu}$ örnekten çıkarabileceğimiz iki önemli husus var. Birincisi, zekânın yeni şeyler yaratması için akışı durdurması ve noktalara ayırması gerekir. İkincisi, bir şey bölündüğünde -o şey her ne ise- o olarak kalmaya devam etmez. Zekânın anlamlandırmak için yaptı̆̆ durdurma ve parçalara ayırma işlemi, o şeyin formunu değiştirmiş olur. Anlamlandırma tamamlandığında o şeyin yerinde yalnızca onu temsil eden bir simge kalır. "İçsel hayatımıza da baktığımızda onun, niteliklerin çeşitliliği, gelişimin sürekliliği ve yönelimin birliğinin bir toplamı olduğunu görürüz. Böyle bir hayat, simgelerle temsil edilemediği gibi kavramlar tarafından da temsil edilemez. Çünkü kavramlar, nesnenin yapay bir yeniden yapımından başka bir şey değildir" (Gündoğan, 2013: 35). Bergson'un zekâ ve sezgi ikiliğini simge ile mutlak biçiminde okumak da mümkündür. "Sabit olandan hareket edene doğru giden hazır kavramlarıyla simgesel bilgi izafîdir, yoksa hareketin içine kendini yerleştiren ve bizzat şeylerin hayatına kendini uyarlayan içgörüsel ${ }^{1}$ bilgi değil. Bu içgörü bir 'mutlak'a erişir" (Bergson, 2013: 79). Yani zekâ durağanlığa, sezgi ise harekete referans verir. "Kavramlar realiteyi bize ancak dışarıdan temaşa ettirir, onun içerisine sokamazlar. Realitenin kabuğunu delip içine nüfuz ettiren dinamik hayallerdir" (Topçu, 2015: 84). Zekânın işlevi gerçeğin kendisini bir noktada yakalamak ve onu elverişli bir koda dönüştürmektir.

\section{Zekânın esaslı işi kavram (concept)lar ve tahliller yapmaktır. Kavram asla realiteyi tanıtıcı değildir. $O$ ancak (elverişli bir sembol)dür. Bir tercüme, bir nokta-i nazar, realitenin bir gölgesi veya esas itibariyle pratik bir şemadır. Herhalde kavram, realitenin bütününden koparılmış bir parçadır; fotografik veya daha ziyade sinematografik bir görüştür (Bergson'dan akt. Topçu, 2015: 78-79).}

Zekâ tarafından yaratılan kavramlar, gerçeğin başka bir düzleminde kullanılmak üzere kodlanırlar. İnsan, hayatın akışı içinde bazı duraklara ihtiyaç duyar. Kavramlar bu amaçla yaratılır, fakat hiçbir zaman akış içindeki gerçeğin yerini alamazlar. "Belirli bir bakış açısından meydana getirilmiş bir temsil, birtakım simgelerle yapılmış bir tercüme, görünüşünün elde edildiği nesneye/konuya veya onu ifade etmede kullanılan simgelere kıyasla daima gayrimükemmel kalır. Buna karşılık mutlak olan, her ne ise mükemmelen o

1 Çevirmen, Türkçede yaygın bir biçimde "sezgi" olarak kullanılan "intuition" kelimesini "içgörü" olarak çevirmiştir. 
olması bakımından mükemmeldir" (Bergson, 2013: 42). Karşılaştığımız bir problem, hayatımız boyunca yaslanacağımız bir deneyime dönüşür. "Her deneyimimiz, örtük olarak bütün geçmişimizi içinde taşır, bütün geçmişimizce belirlenir, ama öngörülemez biçimde yeni olmayı da bırakmaz" (Yücefer, 2014: 30). Bir başkasının deneyimi, kavramlar aracılığıyla ne kadar etkili bir biçimde aktarılsa da kendi deneyimimizin yerini tutmayacaktır. Gerçeği yalnızca kavramlar çerçevesinde düşünmek, gerçek algısını sarsar. "Gerek dış gerekse iç dünya daimî akış ve hareket halinde olduğu halde onu sabit kelimelerle ifade etmek, durağan kavramlarla anlamaya çalışmak, düşüncenin önünde bir engeldir" (Altınörs, 2013: 33).

Dil, Peirce'ın simgesel gösterge adını verdiği göstergelerden meydana gelen kavramlar bütünüdür. İnsan iletişiminin yapı taşıdır. İnsanlar içgüdüsel olarak dil öğrenmeye meyillidirler, çünkü dil işlevselliği bakımından eşsizdir. Fakat Bergson'a göre dil, tüm yararlı işlevleri bir yana, insanların algı dünyasını sınırlandıran bir işleve de sahiptir. Çünkü dil yapısı gereği sınırlandırıcıdır. "Kavramsal düşüncenin soyutlamaya ve genelleştirmeye dayalı yapısı, Bergson'un dili bir engel olarak değerlendirmesinin başlıca sebebidir" (Altınörs, 2013: 30). Bir duyguyu dil aracılığıyla aktarma çabası, Bergson'un ifade ettiği sınırlılığı anlatmak için iyi bir örnek teşkil eder. Bu bakımdan Bergson, analiz ve tercümeye de bazı eleştiriler getirmektedir. Ona göre analiz hareketsiz olan üzerinde işlem yaparken sezgi, hareketlilikte veya aynı manâda sürede konumlanır (Bergson, 2013: 65). Tahlil veya analiz, bir dilden başka bir dile yapılan tercümeye benzer, aslında fikrin semboller halinde inkişaf ettirilmesinden başka bir şey değildir (Topçu, 2015: 79). Bu inkişaf, bizi asıl olana doğru götürür, ancak asla aslına vardırmaz.

Bergson' un dile ve tahlile getirdiği tüm bu eleştirileri, onun zekâ ve sezginin birbirinden ayrılmaz bir biçimde çalıştığı ve birbirlerinin yerine geçemeyeceği düşüncesinden ayrı ele almamak gerekir. Felsefesini dilin tüm zenginliklerini kullanarak aktaran ve felsefi eserleriyle Nobel Edebiyat Ödülüne layık görülen Bergson'un dile getirdiği eleştiriler, dilin imkânlarını hafife aldığı anlamına gelmez. “Dil kavramları, kalıpların ve kuralların alanıyken, Bergson'un kendi felsefî söyleminin de en mânidar örneklerinden biri olduğu gibi, bir yandan da yerleşik kalıpları kırmaya ve yeni üslûplar yaratmaya imkân tanımaktadır. Böylece dil, muhafaza etmek kadar yaratmanın da aracıdır" (Altınörs, 2013: 36). Bergson'un dile ve kavramlara getirdiği eleştiri, aynı doğrultuda göstergebilimsel film çözümlemelerine de getirilebilir.

\section{Göstergebilimsel Yönteme Eleştirel Bir Bakış}

Film eleştirisini bilimselleştirme iddiasında olan göstergebilimsel çözümleme, bir filmi en küçük parçalarına (göstergelere) bölerek, filmin gizil anlam yapılarını ortaya çıkarmayı amaçlamaktadır. Bölme işleminin gerekçesi, bir filmde göstergeler dişında herhangi bir anlam yaratma biriminin olmadığ1 yönündeki düşüncedir. “Semiyoloji (Göstergebilim), bir metin kodu aracılığıyla sistematik biçimde taşınan mesajlar dişında bir anlam türünü ele almayı reddeder. Böylece dolayımsız (immediate) anlam kavramını reddeder. Sinemada mümkün olan her olası anlam (meaninig) bir kodla aracılık edilmiş (mediated) olmalıdır" (Andrew, 2010: 332). Bu düşünceye göre bir film, o filmin içinde bulunan tüm çekimlerin toplamına eşittir. Sayısal olarak doğru olan bu önerme, gerçeği ne kadar yansıtmaktadır? Kek yapımında kullanılan un, şeker gibi malzemeleri ayrı ayrı yemek, kek yemek anlamına gelir mi? Ya da bu malzemelerden ayrı ayrı yola çıkarak keki tarif etmek, keke dair zihinde oluşması gerekenleri tamamen kapsayabilir mi? Karanlık bir sinema salonunda, sesler ve görüntüler vasitasıyla yaratılan atmosferin içinde izlenen filmin insan zihninde yarattığ1 alg1 ile her bir sahnesi 
ayrı ayrı izlenen filmin insan zihninde yarattığı algı aynı olabilir mi? Veya her bir sahneyi ayrı ayrı düşünüp analiz etmek, o filmin filmsel gerçekliğini anlamamıza ve aktarmamıza ne kadar imkân sağlayabilir? Yusuf Atılgan, "Aylak Adam" adlı romanında "sinemadan çıkmış insan" olarak adlandırdığı bir insan türünden şöyle bahseder: "Çağımızda geçmiş yüzyılların bilmediği, kısa ömürlü bir yaratık yaşıyor. Sinemadan çıkmış insan. Gördüğü film onlara bir şeyler yapmış. Salt çıkarını düşünen kişi değil. İnsanlarla barışık. Onun büyük işler yapacağı umulur. Ama beş-on dakikada ölüyor. Sokak sinemadan çıkmayan insanlarla dolu..." (Atılgan, 1985: 20-21). Burada Atılgan'ın betimlediği üzere bir sinema filmi seyretmek insan üzerinde göstergelerle veya yapılarla açıklanamayacak etkiler uyandırabilir. "Göstergebilimciler, bir filmi çözümlemek amacıyla ele aldıkları zaman, zamanın akışını durdurur ve doğada bir nesne gibi olan film üzerinde çalışma riskini göze alır" (Andrew' den akt. Özden, 2004: 141). Bu yöntemle filmdeki bazı şeyler açığa kavuşabilir, fakat bu şeylerin açığa kavuşması için yapılan durdurma, bölme ve kavramsallaştırma işlemleri, filmin büyük bir bölümünün analiz dışında kalmasına neden olur. Bu büyük bölüm, insan zihninin filmin akışı içinde algılayabileceği sezgisel anlam evrenidir. "Filmi yapan kişi, sözel bir dilin kullanıcısından farklı olarak bir anlamı parça parça inşa etmez. Doğal dünyadan çıktı̆̆ı gibi bir anlatım akışını organize eder, buna işaret eder ve serbest bırakır" (Andrew, 2010: 330). Bu nedenle sinema filmlerinin sözel diller gibi çözümlenmeleri birçok sorunu da beraberinde getirir. Bergson'a (1959: 13) göre "bizim toptan kavrayacağı yerde filmi hayal mayal teferruatlandırmaya mahkûm olan kendi kabiliyetlerimizin sakatlığını ifade eder". Aslında "kabiliyetimiz", filmi bir bütün olarak izlediğimizde toptan kavramaya imkân verir. Fakat kavradığımız şeyi durdurarak, parçalayarak veya kavramsallaştırarak aktarmamız mümkün değildir.

Lotman, "Sinema Göstergebilimi” adlı eserinde Blow-Up (Cinayeti Gördüm, Michelangelo Antonioni, 1966) filminin öykü gelişimi ile göstergebilim yöntemi arasında bir analoji ilişkisi kurmuştur: Öncelikle filmin ilk dakikalarında parktaki mekânsal süreklilik, yerini fotoğrafın iki boyutlu yüzeyine bırakmıştır. Daha sonra filmin başkarakteri Thomas'in (David Hemmings) çektiği fotoğrafları karanlık odada incelemesi ile sahnenin kesintisiz akışı gizli birimlere, tek tek çekimlere bölünmüş ve fotoğraf bölümlerinin büyütülmesiyle de daha küçük birimlere ayrıştırılmıştır. Böylece elde edilen gizli birimler, deşifre edilmesi gereken birer gösterge halini almıştır. Bu yöntemle Lotman (2012: 150), düzenlenmiş olguların gizlerini açığa vurduğunu ve yaşamı sadece saptamak yerine deşifre edilmesinin de gerekli olduğunu belirtmiştir. Blow-Up filmi burada göstergebilimi açılamak ve savunmak amacıyla ele alınmıştır. Fakat Lotman'ın ele aldığı biçimiyle bu film, göstergebilim eleştirisi için de oldukça uygun bir örnektir. Filmin başkarakteri Thomas, bir fotoğrafçı olarak akış içindeki gerçeği durdurmuş ve çerçeve içine almıştır. Daha sonra çektiği fotoğrafları basması, onları büyüterek ve parçalara ayırarak bağlamından koparması Lotman'ın belirttiğinin aksine Thomas'ı gerçeğe ulaştırmamıştır. Filmin birçok bölümünde ayrıntılandırıldığı üzere Antonioni' nin amacı, "gerçek" fikrinin izafi oluşunu izleyiciye aktarmaktır. Thomas, çektiği fotoğraflardan ve o fotoğraflara uyguladığ işlemlerden sonra gerçeğe ulaştığı kanısındadır. Fakat filmin tümünde, gerçeğin Thomas'ın fotoğraflarından yola çıkarak zannettiği şey olup olmadığı kasıtlı olarak muğlak bırakılmıştır. Filmin sonunda tenis kortunda hayali bir topla maç yapan pantomimcileri izleyen Thomas, sahanın dişına kaçan hayali topu sahaya geri atar. Bu hayali tenis maçı, film boyunca üzerinde durulan "gerçeğin göreceliği" meselesini somutlaştıran ve altını çizen bir metafor olarak kullanılmıştır. 
Buraya kadar anlattıklarımızı somutlaştırmak için bir filmi ve o filmin göstergebilimsel olarak çözümleniş biçimini örnek olarak ele alalım. "Sinemada Anlamın Oluşma Sürecine Bir Örnek: Nerdesin ${ }^{2}$ Firuze" (Uluyağc1, 2006) adlı makalede göstergebilim, "filmi bir metin olarak okumanın yöntemi" olarak ele alınmış ve bu yöntemle Neredesin Firuze (Ezel Akay, 2004) adlı film "bir metin olarak" irdelenmiştir. Yazının ilerleyen satırlarında sinema filminin bir iletişim biçimi olarak ele alınması nedeniyle filmin bir metin gibi çözümlendiği anlaşılmaktadır. Sinema elbette görsel ve işitsel göstergeleri ileten bir işleve sahiptir. Fakat bu, sinemanın yalnızca bir niteliğinden ibarettir. Sinema her şeyden önce bir sanattır. Elbette anlamlar yaratır, fakat bir sinema filmi, yarattığ tüm anlam parçalarının çok ötesinde bir olgu olarak ele alınmalıdır. Yazar, filmde yer alan renkler ve sayıların anlamları üzerinden filmi çözümleme yoluna gitmiştir. Buna göre karakterlerin giydiği kıyafetlerin renkleri, o karakterler ve filmin tamamı ile ilgili çeşitli yan anlamların ortaya çıkmasına imkân sağlamıştır. Yine yazara göre epizodik anlatımın tercih edildiği filmde yer alan her bölümün rakamı da filmle ilgili bazı örtük anlamların ortaya çıkarılmasını sağlamıştır. Filmi bu biçimde "okuma" tercihi, film ile ilgili birçok anlatısal olgunun çözümlemeye konu edilmemesine neden olmuştur. Oysa filmi felsefi bir bakış açısı ile bütünsel olarak ele aldığımızda ilkin burada yönetmenin gerçek, gerçeklik ve gerçeklik inşası ile ilgili bir anlatımı tercih ettiğini görürüz. Tıpkı daha önce söz ettiğimiz Blow-Up filmi gibi Neredesin Firuze filmi de gerçek meselesini irdeleyen bir yapıya sahiptir. Bu bakımdan iki film arasındaki temel fark, Blow-Up filminin modernist bir anlayışla çekilmesine karşılık Neredesin Firuze filminin daha çok postmodern kurgu ve anlatım tekniklerini kullanmış olmasıdır. Filmin görsel ve anlatı yapısına karnavalesk karmaşa hakimdir. Filmin kadın başkarakteri Firuze (Demet Akbağ), gerçeklik yanılsaması yaşayan bir paranoid şizofreni hastasıdır ve bu durum filmin sonuna kadar açıklanmaz. Filmdeki birçok erkek karakter de sürekli gerçeği çarpıtan davranışlar sergilerler. Burada filmin anlatısal yapısı ve gerçekliği ele alış biçimi aslında filmin ana meselesi olan İstanbul müzik piyasasının niteliğini ortaya koymaktadır. $\mathrm{Bu}$ yüzden filmin tamamı bir şenlik havasında ve gerçeklik yanılması içinde geçer. Filmdeki görsel veya söze dayalı hiçbir kod, filmi bir oturuşta izleyen bir kişinin belleğinde yaratılan anlamı ve duygulanımı açıklamaya yetmez. Hatta filmin içinde barındırdığı kaos nedeniyle, film her izlendiğinde daha önceki anlam ve duygulanımlar birleşerek bambaşka anlamlar ortaya çıkar. Tüm bu anlam dünyası ise ancak filmsel zamanın Bergsoncu bir biçimde ele alınması ve sezginin devreye sokularak irdelenmesi ile serimlenebilir.

Yukarıda anlatmak istediğimiz aslında göstergebilimsel film çözümleme yönteminin bir filmin analiz edilmesi için yanlış bir yöntem olduğu değildir. Burada yalnızca Bergson felsefesi ile bakıldığında bu yöntemin kimi eksikliklere sahip olduğu ortaya konulmaktadır. İmgelerin yan yana gelerek çeşitli düz ve yan anlamlar yaratması matematiksel bir gerçektir. Bu gerçeği serimleyen en bariz örneklerden biri, Lev Kuleşov'un sinemada montajın gücünü ortaya koymak için gerçekleştirdiği deneylerdir. Kuleşov bu deneylerde, iki durağan imgenin yan yana yer alması ile bir anlam yaratıldığını ispatlamaktadır. Fakat üzerinde durduğumuzasıl mesele, bu matematiksel gerçeğin bir filmi açıklamak-açımlamak için yeterli olamayacağıdır. Örneğin Peter Weir'ın yönettiği The Truman Show (1998) adlı filmin göstergebilimsel analizini yaptığımızı düşünelim. Başkarakter Truman Burbank nasıl bir illüzyon içinde yaşıyorsa, filmi izleyen seyirci de seyir sırasında benzer bir illüzyona kendini kaptırır. Daha sonra ise Truman ile film seyircisi, filmin anlatısı içinde gizlenmiş ipuçlarını eşzamanlı olarak fark ederek filmin sonunda gerçeğe ulaşmayı başarır. Filmi sekanslara ve hatta daha küçük parçalara

2 Filmin adı "Neredesin Firuze" olmasına rağmen, adı geçen makalenin tamamýnda "Nerdesin Firuze" olarak yazýlmýptýr. 
bölerek aslında filmin sonuna kadar bu gerçeklik yanılsamasının nasıl inşa edildiğine dair ipuçlarına ulaşabiliriz. Fakat bunların hiçbiri, filmi izlerken gerçeklik ile ilgili içimizde yeşeren duygulanımı tarif edemez. Bu duygulanımın nedeni, gerçeklik ile aramızda var olan bağın film seyri sırasında sarsılmaya başlamasıdır. Filmin akışı içinde seyircinin zihninde oluşan bu problematik, aslında yan yana gelen imgeler sonucunda ortaya çıkmıştır. Fakat bu problematiği irdelemek ancak filmin akışı içinde çalışan sezgiye başvurularak mümkün hale gelebilir. Bir filmin izlenmesi sırasında, izleyicinin içinde bulunduğu zaman akışına, filmin daha yoğun olan alternatif zaman akışı dâhil olur. Bu alternatif akış, gerçek zamansal akışı değiştirir ve seyircinin algılayışını etkiler. Bu nedenle bazı filmler izlendiği sırada çok uzun süredir devam ediyormuş gibi hissetmemize neden olabilir. Göstergebilimsel analiz, sadece filmin akışı içinde gerçekleşebilen bu değişimi irdeleyemez. Bu, ancak felsefi bir düşünme biçimi ve edebî tarif ile mümkündür.

\section{Sonuç}

Göstergebilim, Ferdinand de Saussure ve Charles Sanders Peirce'ın öncü çalışmaları neticesinde sosyal bilimler alanında sıkça kullanılan bir araştırma yöntemi haline gelmiştir. Fransız sinema kuramcısı Christian Metz ise bu yöntemi film çalışmalarına uygulamış ve bu alanda önemli bir eğilime kapı aralamıştır. Bilimsel bir yöntem olarak göstergebilimin amacı, göstergeler ve göstergeler arasındaki ilişkilerden yola çıkarak anlamı yaratan yapıları ortaya koymaktır. Bu doğrultuda düşünüldüğünde sinema göstergebilimi de filmlerin içinde yer alan göstergelerden yola çıkarak tüm sinema filmleri için geçerli olabilecek anlam prensipleri ortaya koymayı amaçlamaktadır. Sinema göstergebilimi anlayışına göre sinemasal anlam, anlamı yaratan göstergelerin toplamına eşittir. Bu nedenle bir sinema filminin insan zihninde oluşturduğu anlamı ortaya koymak ve incelemek için anlamı yaratan gösterge birimlerinden ve bu birimler arasındaki yapısal ilişkiden hareket etmek gerekir.

Bergson, ortaya koyduğu felsefesi ile insan algılayışının iki kanalla gerçekleştiğini belirtmiş ve o dönemde yaygın olan insan aklını her şeyin önüne koyan rasyonalist ve bilimselci anlayışa karşı çıkmıştır. Buna göre insan, zekâsı ile durağan şeyleri algılayabilmektedir. Akış halinde olan, yani değişimin durmadan gerçekleştiği devinim halinde olan şeyleri ise ancak durdurarak algılayabilmektedir. Bir insan zihninin akış içinde algılayabilmesi için sezgiyi devreye sokması gerekir. Göstergebilimsel film çözümlemeleri, filmin akışı içinde gerçekleşen sezgisel anlamı analiz dışı bırakmaktadır.

İzleyici, bir sinema filmini hem zekâ yoluyla, hem de filmin akışı içinde sezgi yoluyla algılar. Kurmaca bir film bittikten sonra her seyircinin zihninde filmin öykü şeması az çok belirir. Filmle ilgili önsel bilgiler, karakterlerin adları, simaları veya konuşmaları da zekâ yoluyla algilanır. Tüm bunlar bilimsel bir çalışmaya konu da olabilirler. Fakat filmin anlam evreni bunlardan ibaret değildir. Filmi izleyen kişinin, filmin akışı içinde zihninde oluşan anlamlar da filmin anlam evrenine dahildir. Bu nedenle bir film çözümlemesi kaleme alan yazar, filmi izleme esnasında oluşan sezgisel anlamı da çalışmasına katmayı denemelidir. Bu nedenle her film çözümlemesi edebi olmak zorundadır. Böylece ele alınan filmin sezgisel anlamını yakalamak ve çözümlemek mümkün olabilir. 


\section{Kaynakça}

Andrew, J. Dudley, (2010). Büyük Sinema Kuramları (Çev. Zahit Atam), İstanbul: Doruk Yayımcilık.

Altınörs, Atakan, (2013). "Bergson ve Dil Anlayışı Üzerine", Henri Bergson (Önsöz), Metafiziğe Giriş, İstanbul: Paradigma Yayıncılık.

Atılgan, Yusuf, (1985). Aylak Adam, İstanbul: İletişim Yayınları.

Barthes, Roland, (1997). Göstergebilimsel Serüven (Çev. Mehmet Rifat, Sema Rifat), İstanbul: Yapı Kredi Yayınları.

Bergson, Henry, (1959). Düşünce ve Devingen (Çev. Miraç Katırcığlu), İstanbul: Maarif Vekâleti Basımevi. Yayıncilik.

Bergson, Henri, (2013). Metafiziğe Giriş (Çev. Atakan Altınörs), İstanbul: Paradigma

Birkiye, Atilla, (1984). Yapısalcılı̆̆ın Eleştirisine Doğru, İstanbul: Varlık Yayınları.

Büker, Seçil, (2012). Sinemada Anlam Yaratma, İstanbul: Hayalperest Yayınevi.

Ehrat, Johannes, (2005). Cinema and Semiotic, Toronto: University of Toronto Press.

Erkman, Fatma, (1987). Göstergebilime Giriş, İstanbul: Alan Yayınc1lık.

Deleuze, Gilles, (2014). Bergsonculuk (Çev. Hakan Yücefer). İstanbul:Otonom Yayınc1lık.

Guerlac, Suzanne, (2006). Thinking in Time: An Introduction to Henri Bergson, New York: Cornell University Press.

Gündoğan, Ali Osman, (2013). Bergson, İstanbul: Say Yayınları.

İnceoğlu, Çağrı, (2014). “Türkiye'de Akademik Sinema Yazınını On Yılı (2002-2011): Bibliyometrik Bir Analiz", Selçuk İletişim Dergisi, 8(3), s. 182-200. Kitap.

Lotman, Yuriy M., (2012). Sinema Göstergebilimi (Çev. Oğuz Özügül), Ankara: Nirengi

Metz, Christian, (2012). Sinemada Anlam Üstüne Denemeler (Çev. Oğuz Adanır), İstanbul: Hayalperest Yayınevi.

Öztürk, Serdar, (2018). Sinema Felsefesine Giriş, Ankara: Ütopya Yayınevi.

Özden, Zafer, (2004). Film Eleştirisi, Ankara: İmge Kitabevi Yayınları.

Piaget, Jean, (1999). Yapısalcılık (Çev. Ayşe Şirin Okyavuz Yener), Ankara: Doruk Yayımcilik.

Rifat, Mehmet, (1990). Genel Göstergebilim Sorunları, İstanbul: Sözce Yayınları.

Stam, Robert, (1986). "Film and Language", Studies in the Literary Imagination, 19, s. 109-130.

Şendur Atabek, Gülseren ve Atabek, Ümit, (2007). Medya Metinlerini Çözümlemek İçerik, Göstergebilim ve Söylem Çözümleme Yöntemleri, Ankara: Siyasal Kitabevi.

Topçu, Nurettin, (2015). Bergson, İstanbul: Dergâh Yayınları. 
Uluyağc1, Canan, (2006). "Sinemada Anlamın Oluşma Sürecine Bir Örnek: Nerdesin Firuze", Selçuk İletişim Dergisi, 4 (2), s. 221-233.

Wollen, Peter, (1989). Sinemada Göstergeler ve Anlam (Çev. Zafer Aracagök), İstanbul: Metis Yayınları.

Yücefer, Hakan, (2014). "Deleuze'ün Bergsonculuğuna Giriş", Gilles Deleuze, Bergsonculuk, İstanbul: Otonom Yayıncilık.

Yücel, Tahsin, (1982). Yapısalcılık, İstanbul: Ada Yayınları. 